\title{
When Public Utilities Like to Talk on Facebook
}

\author{
Sebastian Martin 1
}

Published online: 6 November 2017

(C) The Author(s) 2017. This article is an open access publication.

\begin{abstract}
As the leading social media tool, Facebook is increasingly becoming an important channel for twosided stakeholder communication in the energy sector. Even though public utilities more and more all relying on such virtual communication, little is known regarding the communication-related factors and their interdependencies. This study aims to reduce this research gap by analysing correlations between a public utility's specifications, communication interactivity, the resources spent and the outcome of the Facebook conversation. In 2016, an online questionnaire was sent to German, Austrian and Swiss utility companies. The empirical data of the 139 utilities that responded fully support relationships between the communication interactivity and the invested resources as well as the outcomes of a communication. In this way, the results provide new insights for scholars and practitioners into the Facebook conversations of public entities.
\end{abstract}

Keywords Social media $\cdot$ Facebook $\cdot$ Stakeholder engagement $\cdot$ Stakeholder dialogue $\cdot$ Public utilities

\section{Die Kommunikation öffentlicher Energieversorger auf Facebook}

Zusammenfassung Zunehmend bieten Energieversorger ihren Anspruchsgruppen die Möglichkeit zu einer virtuellen Facebook-Kommunikation. Somit gewinnt Facebook als

Sebastian Martin

Sebastian.Martin@fh-linz.at

1 Faculty for Health and Social Sciences, University of Applied Sciences Upper Austria, Garnisonstrasse 21, 4020 Linz, Austria führendes Social Media Tool auch in der Energiebranche an Relevanz. Wesentliche kommunikationsbezogene Faktoren sowie deren Zusammenhänge sind jedoch unzureichend bekannt. Um bestehende Forschungslücken zu reduzieren, sollen anhand dieser Studie die Wirkungszusammenhänge zwischen den Unternehmensspezifika, der Kommunikationsinteraktivität, den verwendeten finanziellen und personellen Mitteln sowie dem Ergebnis einer Facebook Kommunikation analysiert werden. Hierzu wurde der Link zu einem Online-Fragebogen an deutsche, österreichische und schweizer Energieversorger versendet. Insgesamt nahmen an der Studie 139 Unternehmen teil. Anhand der empirischen Ergebnisse lässt sich ein Zusammenhang zwischen der Kommunikationsinteraktivität und den investierten Mitteln sowie dem Ergebnis der Facebook Kommunikation nachweisen.

\section{Introduction}

Private firms as well as public organisations-including public agencies - are increasingly focusing stakeholder communication on social media platforms (Mühlbacher and Kornum 2013; Bortree and Seltzer 2009). Regarding the private sector, a comprehensive body of literature already exists concerning virtual communication processes and outcomes (e.g. Kim et al. 2014; Haigh et al. 2013; Swani et al. 2013; Dekay 2012). Similarly, the use of social media in the public sector, especially in government agencies, is progressively focused (Manetti et al. 2016; Oliveira and Welch 2013; Mossberger et al. 2013; Bonsón et al. 2012). However, the public management literature on social media can still seen to be in its infancy (Sharif et al. 2015; Agostino 2013; Criado et al. 2013). Only a minority of studies emphasizes the application of social media by 
public organisations such as utility companies (Martin and Grueb 2016). Nevertheless, especially public utilities are confronted with fundamental sectoral challenges. Examples are the increasing competition due to the liberalisation of the European energy sector, the growing amount of products and services, the consumers that suddenly become energy producers as well as-particularly in Germany-the exit from nuclear and fossil-fuel energy (Martin and Grueb 2016; Witt 2013; Dechange and Friedrich 2013). In this challenging environment, Facebook as the leading social media tool seems to allow utilities more of a dialogue with its various stakeholders (Manetti et al. 2016; Statista 2016a, 2016b, 2015; Lovari and Parisi 2015; Cho et al. 2014). An initial study by Martin and Grueb (2016) indicate that most utilities employ Facebook to improve their public relations, reputation/image as well as to increase customers' loyalty, level of awareness and dialog. In this way, 'the majority of companies pay attention to service as well as brand and PR objectives' (Martin and Grueb 2016, p. 13). Further, Martin and Grueb (2016) as well as Martin (2016) identify a growing amount of German, Austrian and Swiss utility companies using Facebook for stakeholder communication. The investigated utilities differ in their size, their public share, the interactivity of their stakeholder communication, their resources spent for Facebook communication and communication outcomes. Due to the explorative character of the two studies, the interdependencies of the described factors were not emphasized. However, in order to more actively manage Facebook conversations, a deeper understanding of the factors influencing these conversations, especially their interdependency, becomes crucial. This paper will contribute to the public management literature on social media by investigating such communication factors and their interaction by using the example of public utilities in Germany, Austria and Switzerland. The results will provide new insights for scholars and practitioners into the Facebook conversations of public entities. Practitioners will also be enabled to more actively manage their Facebook communications.

To meet the research objective, this paper is structured as follows: After the introduction in Sect. 1, Sect. 2 presents the conceptual framework for the study. Critical factors of a Facebook communication are presented and interdependencies proposed. The research design is presented in Sect. 3 and the analysis of empirical findings in Sect. 4. In Sect. 5 and 6 the empirical results are discussed along with research and managerial implications.

\section{Research Framework and Hypotheses}

\subsection{Stakeholder Engagement of Public Utilities Through Facebook}

As public utilities might be strongly affected by a variety of stakeholders (O'Riordan and Fairbrass 2008; Donaldson and Preston 1995), stakeholder theory suggests a consideration of the different stakeholder interests when making decisions (Rasche and Daniel 2006; Phillips et al. 2003; Freeman and Evan 1990). In compliance with the stakeholder theory, the concept of dialogic accounting 'recognizes various points of views and refuses to regard capital markets and investors as 'priority' stakeholders. Dialogic accounting, in short, rejects the idea of a universal narrative, preferring to think of institutions as being beholden to diverse perspectives and the interests of a wide variety of stakeholders' (Manetti et al. 2016, p. 5). According to both theoretical constructs, stakeholder engagement- especially the dialogue as a two sided exchange of information-seems to play a fundamental role in collecting the variety of stakeholder information and expectations (Manetti et al. 2016; Driessen et al. 2013; Freeman 1984). Cuppen (2012, p. 23) describes such stakeholder dialog 'as an organised meeting of stakeholders with different knowledge, values and backgrounds who would otherwise not meet (or not all together)'. As well as the identification and selection of the relevant stakeholders, the dialog comprises the exchange of perspectives as well as a confrontation of different positions (Cuppen 2012). Particularly social networking sites such as Facebook seem to enable the utility to such a dialog with its stakeholders (Manetti et al. 2016; Yang and Kent 2014; Assmussen et al. 2013; Korschun and Du 2013; Bortree and Seltzer 2009). To encourage a dialogue, the utilities should predominantly post information which is perceived as interesting and relevant (Bonsón et al. 2015 , p. 58). Stakeholders may respond in a way so as to express their thoughts, emotions, intentions as well as behavior (Baltar and Brunet 2012; Chun and Reyes 2012). The outcome of such dialogue might not necessarily be a consensus. Rather, the dialogue often is seen as a tool to collect and understand the different stakeholder perspectives and expectations (Manetti et al. 2016).

\subsection{Factors Influencing the Outcome of Stakeholder Engagement on Facebook}

The outcome of the utilities stakeholder engagement on Facebook might be affected by a variety of factors, such as the company's specification (Sharif et al. 2015; Nah and Saxton 2012), the communication interactivity (Bauer et al. 2012) and the resources spent (Picazo-Vela et al. 2012). The 
Fig. 1 Research framework. (Source: Own compilation)

\section{Stakeholder engagement on Facebook}
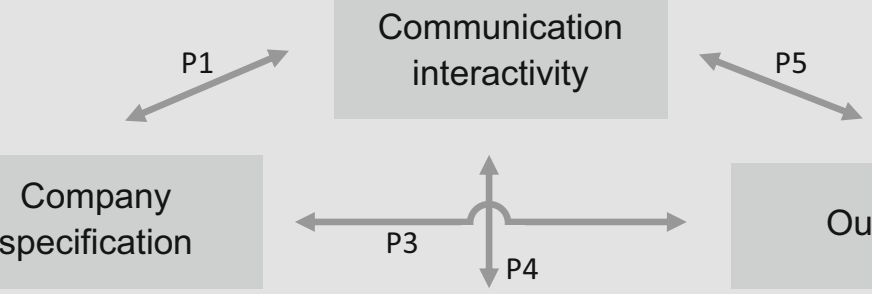

\section{Outcome}

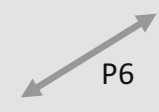

$\leftrightarrow$ = Propositions of variable interdependency

proposed interdependencies of the factors are summarized in Fig. 1.

Company Specifications Utilities differ in their company size. As large organizations generally possess more resources, they are capable of investing a higher budget for Facebook communication and therefore might have different communication processes and outcomes than smaller utilities (Nah and Saxton 2012). Another aspect of the company's specifications is ownership structure. Sharif et al. (2015) emphasizes the fundamental differences between public sector organizations and private sector firms. To be more precise, public organizations and private firms seem to have different cultural environments for an adoption of social media communication which might strongly impact stakeholder interactivity on Facebook and its outcomes (Sharif et al. 2015; Mergel 2012).

Communication Interactivity A stakeholder dialog comprises a symmetrical two-sided flow of information between the utility and its various stakeholders. By releasing information, the utility may explain its company behaviour and stimulate stakeholder response (Cho et al. 2014; Pedersen et al. 2013; Merilainen and Vos 2011; Bortree and Seltzer 2009; Wallsten 2007; Pedersen 2006). The degree to which stakeholders engage in this dialogue depends on their ability to affect the communication process (Manetti et al. 2016; Pedersen 2006). In comparison to the one-way communication of traditional media, Facebook's special strength seems to lie in two-sided interaction, enabling the company to collect stakeholder information, increase stakeholder engagement (Sharif et al. 2015; Agostino 2013; Hofmann et al. 2013; Mergel 2013) and strengthen stakeholder relationship (Kim et al. 2014; Yi et al. 2013; Waters et al. 2009). The communication interactivity might be affected by the company's specifications (Sharif et al. 2015;
Mergel 2012) and the available resources (Picazo-Vela et al. 2012).

Resources As stated before, a link between the company size and the invested resources might be assumed (Nah and Saxton 2012). The amount of resources employed may affect stakeholder communication in such a way that, for example, a 'lack of resources and procedures could undermine the accuracy of the information posted on social media' (Picazo-Vela et al. 2012, p. 506).

Outcome 'Organizations' posts on Facebook are generally visible to anyone browsing their page but are only pushed to the organization's circle of fans' (Garcia-Milian et al. 2012, p. 173). Fans may automatically receive these information (Facebook 2017a), depending on several factors such as the individual Facebook user settings (Facebook 2017b) or the popularity of the postings (Facebook 2017c). The larger the amount of fans, the more stakeholders may continually be reached and engaged (Garcia-Milian et al. 2012). Since 'Facebook marketing largely depends on fans' word-of-mouth communications, the more fans a business Facebook page has, the more likely its Facebook marketing is to be effective' (Leung and Tanford 2016, p. 316). Bauer et al. (2012) states that information access can be seen as a chief motive to become a fan of a utility's Facebook account. Similarly, Swani et al. (2013, p. 287) highlight that '[b]uilding account fanbases can be accomplished by focusing on developing relevant message content'. In addition to content, the frequency of postings seems to positively affect the number of fans (Bürger 2015). Beyond these communication aspects, the amount of fans might also be influenced by the company's specification (Sharif et al. 2015; Nah and Saxton 2012) and the resources spent (Picazo-Vela et al. 2012). 
Table 1 Variables and measures. (Source: Own compilation)

\begin{tabular}{|c|c|c|c|c|}
\hline \multicolumn{3}{|l|}{ Variables } & $\begin{array}{l}\text { Authors referring to the } \\
\text { importance of this indicator }\end{array}$ & Operationalization used in this study \\
\hline \multirow[t]{2}{*}{$\begin{array}{l}\text { 1. Company } \\
\text { specification }\end{array}$} & \multicolumn{2}{|c|}{ 1.1. Company size } & Nah and Saxton (2012) & $\begin{array}{l}\text { Number of employees: } 1 \text { (1-49 employ- } \\
\text { ees), } 2 \text { (50-249 employees), } 3 \text { ( } 250-599 \\
\text { employees), } 4 \text { (600-1200 employees), } \\
5 \text { (>1200 employees) }\end{array}$ \\
\hline & \multicolumn{2}{|c|}{ 1.2. Ownership structures } & Sharif et al. (2015) & Public share in percentage \\
\hline \multirow[t]{3}{*}{$\begin{array}{l}\text { 2. Communication } \\
\text { interactivity }\end{array}$} & \multirow[t]{3}{*}{$\begin{array}{l}\text { Calculated } \\
\text { Interactivity } \\
(=2.1 .+ \\
2.2 .+2.3 .)\end{array}$} & $\begin{array}{l}\text { 2.1. Average } \\
\text { frequency }\end{array}$ & Pedersen et al. (2013) & $\begin{array}{l}\text { Several times a day, once a day, several } \\
\text { times a week, at least once a week, sev- } \\
\text { eral times a month, once a month, less } \\
\text { than once a month }\end{array}$ \\
\hline & & $\begin{array}{l}\text { 2.2. Rapidity of } \\
\text { response }\end{array}$ & Manetti et al. (2016) & $\begin{array}{l}\text { Within } 24 \mathrm{~h} \text {; within two working days; } \\
\text { within one week; it takes longer than one } \\
\text { week; we do not reply to comments at all }\end{array}$ \\
\hline & & $\begin{array}{l}\text { 2.3. Perceived } \\
\text { interactivity }\end{array}$ & Pedersen et al. (2013) & Interactive, active, reactive, passive \\
\hline \multirow[t]{2}{*}{ 3. Resources } & \multicolumn{2}{|c|}{ 3.1. Time resources } & $\begin{array}{l}\text { Manetti et al. (2016); Picazo-Vela } \\
\text { et al. (2012) }\end{array}$ & $\begin{array}{l}\text { Total working hours for the Facebook } \\
\text { account per week }\end{array}$ \\
\hline & \multicolumn{2}{|c|}{ 3.2. Monetary resources } & & $\begin{array}{l}0-15,000 \text { euro; }>15,000-30,000 \text { euro; } \\
>30,000-45,000 \text { euro; }>45,000-60,000 \\
\text { euro; }>60,000-75,000 \text { euro; }>75,000 \\
\text { euro }\end{array}$ \\
\hline 4. Outcome & \multicolumn{2}{|c|}{ 4.1. Number of fans on Facebook } & $\begin{array}{l}\text { Leung and Tanford (2016); Bauer } \\
\text { et al. (2012); Garcia-Milian et al. } \\
\text { (2012) }\end{array}$ & Number of fans \\
\hline \multicolumn{3}{|l|}{ Control variable } & Authors & \\
\hline \multicolumn{3}{|c|}{ 5. Year of account creation } & $\begin{array}{l}\text { Criado et al. (2013); Mergel and } \\
\text { Bretschneider (2013) }\end{array}$ & Year the Facebook account was created \\
\hline
\end{tabular}

\section{Research Design and Methods}

In February 2016 an online survey was launched to 1280 Austrian, German and Swiss utilities. All utilities are either members of the Austrian Energy Association (Österreichs Energie e. V.), the German Association of Energy and Water Industries (BDEW) or the Federation of Swiss electricity companies (VSE). The survey was mainly comprised of multiple choice questions, focussing on the described key items: (1) company specifications, (2) communication interactivity, (3) resources spent and (4) communication outcome. To measure such key items, this study uses indicators based on current social media literature.

The indicators company size (Nah and Saxton 2012) and ownership structure (Sharif et al. 2015) are used to describe the company's specification. Communication interactivity, instead, is measured by the indicators: (1) average frequency of the information provided (Pedersen et al. 2013), (2) rapidity of response (Manetti et al. 2016) and (3) perceived interactivity of communication on Facebook (Pedersen et al. 2013). In order to present the interdependencies of the research framework in a more clearly arranged manner, the values of these three ordinal indicators were in a first step summated to the indicator "calculated interactivity". In a second step the correlation of the three communication indicators are analysed separately. Resource, as a key item, is subclassified in time and monetary resources. Time resources are defined as the deployed time resources for Facebook, including internal full-time personnel, internal parttime personnel, internal apprentices or interns. The item monetary resources describes the budget for the conceptual design and support of the Facebook account in 2016, including costs for internal personnel as well as external services (Manetti et al. 2016; Picazo-Vela et al. 2012). The outcome of a communication process might be multidimensional and measured by a variety of items. Still, due to research economic reasons and in line with the current literature (Leung and Tanford 2016; Bauer et al. 2012; Garcia-Milian et al. 2012), this study concentrates on the amount of Facebook fans as an indicator for the communication outcome.

Mergel and Bretschneider (2013) point out that through continuous engagement in Facebook, public organizations are gaining experience and adopting their application of this communication tool correspondingly. In order to avoid the influence of different experience and adoption levels of the interdependencies focussed, the year an account was created is integrated into this study as a control variable. Correspondingly, a partial correlation analysis is used to measure the degree of linear relationships between the described indicators of the research framework. Such indica- 
Table 2 Findings of the descriptive analysis. (Source: Own compilation)

\begin{tabular}{|c|c|c|c|c|c|c|c|c|c|}
\hline \multirow{2}{*}{$\begin{array}{l}\text { Key } \\
\text { items } \\
\text { Indicators }\end{array}$} & \multicolumn{2}{|c|}{ 1. Company specification } & \multicolumn{4}{|c|}{ 2. Communication interactivity } & \multicolumn{2}{|c|}{ 3. Resources } & \multirow{2}{*}{$\begin{array}{l}\text { 4. Outcome } \\
\text { 4.1. Amount } \\
\text { of fans }\end{array}$} \\
\hline & $\begin{array}{l}1.1 \text {. Com- } \\
\text { pany size }\end{array}$ & $\begin{array}{l}\text { 1.2. Own- } \\
\text { ership } \\
\text { structures }^{\text {a }}\end{array}$ & $\begin{array}{l}\text { 2.1. Fre- } \\
\text { quency of } \\
\text { informa- } \\
\text { tion }\end{array}$ & $\begin{array}{l}\text { 2.2. Ra- } \\
\text { pidity of } \\
\text { response }\end{array}$ & $\begin{array}{l}\text { 2.3. Per- } \\
\text { ceived } \\
\text { interactiv- } \\
\text { ity }\end{array}$ & $\begin{array}{l}\text { Calculated } \\
\text { interactivity } \\
(2.1 .+ \\
2.2 .+2.3 .)\end{array}$ & $\begin{array}{l}\text { 3.1. Time } \\
\text { re- } \\
\text { sources }\end{array}$ & $\begin{array}{l}\text { 3.2. Mon- } \\
\text { etary } \\
\text { resources }\end{array}$ & \\
\hline $\begin{array}{l}\text { Arithmetic } \\
\text { average }\end{array}$ & 3.07 & 69.98 & 4.98 & 4.88 & 3.10 & 13.05 & 14.35 & 1.81 & 6,546 \\
\hline Minimum & 1 & 0.00 & 1 & 2 & 1 & 4 & 0.50 & 1 & 0 \\
\hline Махітит & 5 & 100 & 7 & 5 & 4 & 16 & 80 & 6 & 60,000 \\
\hline $\begin{array}{l}\text { Standard } \\
\text { devia- } \\
\text { tion }\end{array}$ & 1.43 & 37.12 & 1.17 & 0.49 & 0.706 & 1.93 & 16.22 & 1.38 & 13,299 \\
\hline$n$ & 137 & 127 & 62 & 60 & 60 & 58 & 41 & 58 & 70 \\
\hline
\end{tabular}

${ }^{a}$ Two companies did not provide the basic data on the ownership structure. Eight utilities did not provide detailed information on the public share of their mixed ownership

tors are summarized in Table 1. To handle missing values, pairwise deletion is applied. Due to the relatively low number of cases, this study uses an expanded approach of three significance levels $(p<0.01 ; p<0.05 ; p<0.1)$.

The survey was completed by 139 companies (11\%), including 11 Austrian, 105 German and 21 Swiss utilities. Two companies did not provide information on the country where their headquarters are located. Fifty percent of the responding companies stated having an active Facebook account. Regarding the control variable, 14 companies $(21 \%)$ created the account between 2015 and 2016; 22 companies (32\%) between 2013 and 2014; 22 companies (32\%) between 2011 and 2012. Ten companies (15\%) became active in Facebook before 2011.

\section{Analysis of Empirical Findings}

\subsection{Descriptive Analysis}

Company Specifications Regarding the utility's size, $46 \%$ of the 137 companies have between one and 249 employees, $15 \%$ between 250 and 599 employees, $12 \%$ between 600 and 1200 employees and $27 \%$ of the companies have more than 1200 employees. Out of 135 utilities, nearly half of them are entirely public, around two-fifths describe their ownership as mixed and a minority of $15 \%$ are not public. $93 \%$ of the 43 companies that provided additional information on their mixed ownership state their public share is at least $50 \%$. Consequently, the wide majority of participating companies can be seen as public organizations.

Communication Interactivity Concerning the average frequency of the provided information, $24 \%$ of the utilities say they publish postings on their Facebook account once or several times a day. $61 \%$ post several times a week, whereas $15 \%$ are active once a week or less frequently. Within $24 \mathrm{~h}, 94 \%$ of the companies respond to user comments, such as questions, suggestions for improvement or criticism. Three percent answer within two working days and three percent within one week or a longer period of time. $27 \%$ of the companies perceive their communication as interactive, meaning that there is a strong interaction with the Facebook users. $60 \%$ describe an active communication process. These utilities spread new information on their account without external impetus. A reactive or even passive communication style is specified by $13 \%$ of the companies.

Resources The utility's Facebook account is predominantly administered by in-company full time personnel, supported by in-company part-time personnel, apprentices or interns. The total working time on the Facebook account by internal staff accounts for an average of $14.35 \mathrm{~h}$ per week. Ranging from a minimum of half an hour to a maximum of $80 \mathrm{~h}$ a week, the time resources strongly differ among the responding companies. Concerning the monetary resources, nearly $70 \%$ of the companies annually invest up to 15,000 euros in the conceptual design and support of the Facebook account, whereas $17 \%$ spend between 15,001 and 45,000 euros and 16\% more than 45,000 euros.

Outcome On average, a utility's Facebook site counts 6546 fans. Such a fanbase strongly varies among the participating utilities. Some companies state they have no fans while others claim to have 60,000 fans.

The empirical results of the descriptive analysis are summarized in Table 2. 
Fig. 2 Interdependencies of variables in the research framework. Correlation significant at: ${ }^{* * * *} p<0.01 ;{ }^{* *} p<0.05 ;{ }^{*} p<0.1$. (Source: Own compilation)
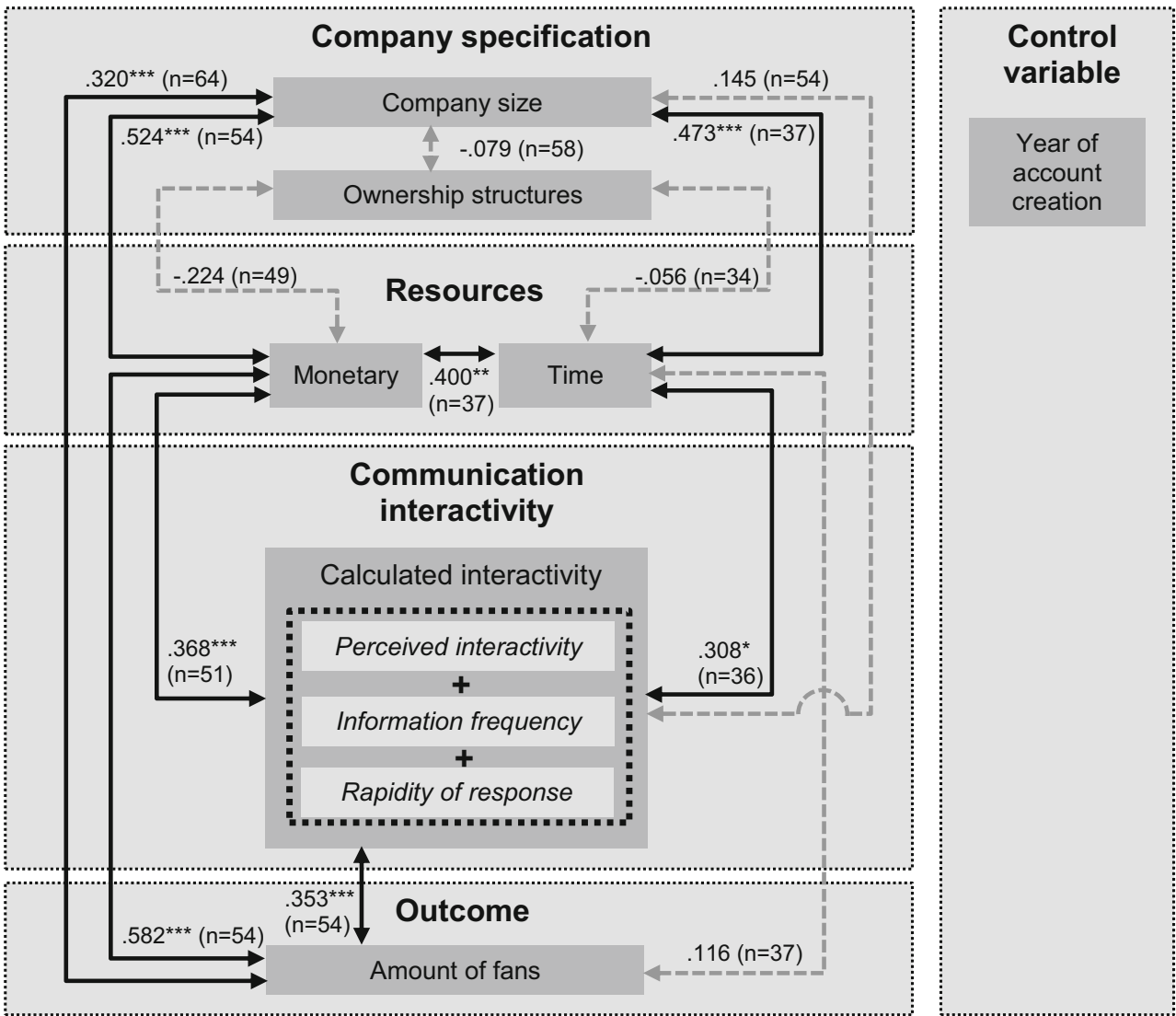

Note: Correlation significant at: ${ }^{* * *} p<0.01 ; * * p<0.05 ; * p<0.1$

\subsection{Relational Analysis}

A linear relationship between the company size and the indicators monetary resources $(0.524, p=0.000)$, time resources $(0.473, p=0.002)$ as well as the amount of fans $(0.320, p=0.009)$ can be verified. However, a relationship between the company size and the ownership structure or the calculated interactivity cannot be proved. When it comes to the key item resource, there exists a linear interrelation between both of the indicators monetary as well as time resources $(0.400, p=0.012)$. No interdependence is detectable between these two resource indicators and the ownership structure. Still, there is a connection between the cumulated indicator "calculated interactivity" and monetary $(0.368, p=0.007)$ as well as time resources $(0.308, p=$ $0.060)$. Additionally, a link between monetary resources and the amount of fans $(0.582, p=0.000)$ can be verified. Regarding the time resources, such a link towards the amount of fans cannot be observed. Nevertheless, the amount of fans is correlated with the "calculated interactivity" $(0.353$, $p=0.008$ ). All described relations are summarized in Fig. 2 .

In order to gain a deeper understanding of the communication-related interdependencies, the correlations of the three communication indicators are analysed in more detail (see Fig. 3). With reference to the information frequency, a linear relationship with the company size $(0.231, p=$ $0.075)$, the amount of fans $(0.333, p=0.009)$, both monetary $(0.336, p=0.011)$ and time resources $(0.296, p=0.068)$ as well as the perceived interactivity $(0.658, p=0.000)$ and the rapidity of response $(0.380, p=0.003)$ can be verified. The perceived interactivity, instead, is interdependent with monetary resources $(0.405, p=0.002)$, the amount of fans $(0.386, p=0.003)$ and the rapidity of response $(0.346, p=$ $0.008)$.

\section{Discussion}

This study proposes a relationship between the company's specifications and the communication interactivity. As key items of the company's specification, company size as well as ownership structure were determined. The indicators of both items do not show a significant correlation with the communication interactivity. Only by increasing the tolerable significance level to $p=0.075$ can a linear relation between the size and communication indicator information frequency be observed. Therefore, even though the literature strongly suggests a link between the utility's specifications and the communication interactivity, the corresponding proposition 1 cannot be supported by the empir- 
Fig. 3 Interdependencies of the communication indicators

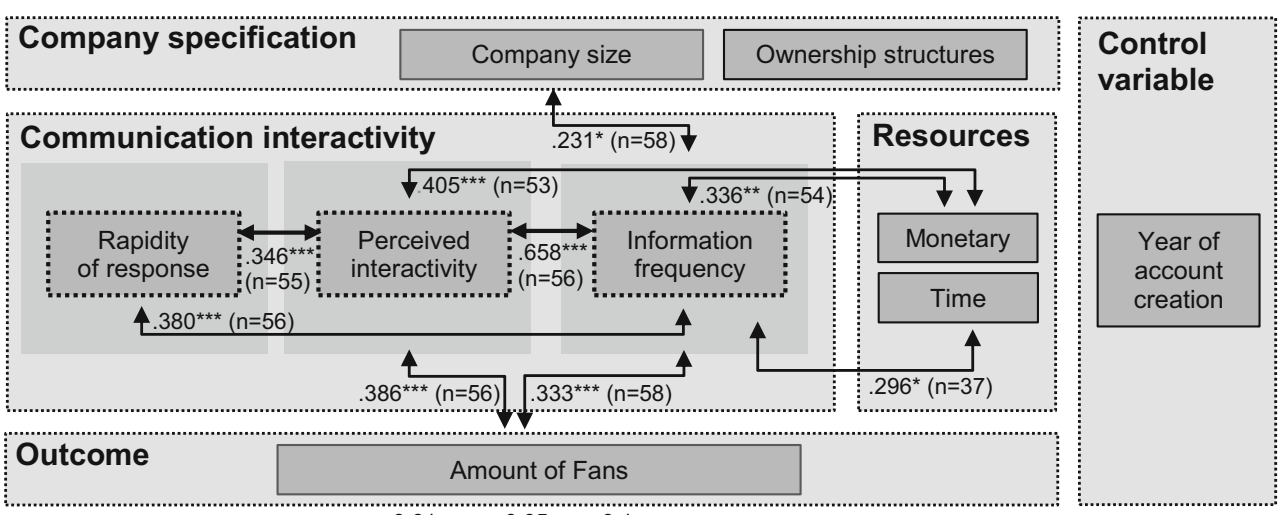

Note: Correlation significant at: ${ }^{* * *} p<0.01 ; * * p<0.05 ; * p<0.1$
Table 3 Support of propositions. (Source: Own compilation)

\begin{tabular}{lll}
\hline Proposition & Support \\
\hline P1 & $\begin{array}{l}\text { Company Specification } \Leftrightarrow \text { Communication } \\
\text { Interactivity }\end{array}$ & - \\
P2 & Company Specification $\Leftrightarrow$ Resources & $(+)$ \\
P3 & Company Specification $\Leftrightarrow$ Outcome & $(+)$ \\
P4 & Communication Interactivity $\Leftrightarrow$ Resources & + \\
P5 & Communication Interactivity $\Leftrightarrow$ Outcome & + \\
P6 & Resources $\Leftrightarrow$ Outcome & $(+)$ \\
\hline
\end{tabular}

ical findings of this study. Concerning proposition 2, there exists a significant linear interrelation between the company size and the monetary resources as well as the time resources spent. These findings reflect the literature emphasizing that large organizations may generally possess more resources and therefore may be capable of investing a higher budget for Facebook communication (Nah and Saxton 2012). Nonetheless, this study is not able to identify a correlation between the ownership structure and the described resources. Therefore, proposition 2 is only partly supported. Regarding proposition 3, a correlation between company size and amount of fans is observed. This finding might to some extend be explained by the fact that in general large companies may have more customers than smaller companies. As customers might be directly affected by the company and therefore be especially interested in a stakeholder dialog with the utility, a higher number of customers might positively impact the amount of current and potential Facebook fans. In contrast to company size, a relationship between ownership structure and amount of fans cannot be found. Thus, proposition 3 can only be partly supported. With respect to propositions 1 and 3, the current literature highlights that public organizations and private firms seem to have different cultural environments for an adoption of social media communication which might strongly impact stakeholder interactivity on Facebook and its outcomes (Sharif et al. 2015; Mergel 2012). Such theoretical assumptions could neither be proved nor disproved in this study.

Proposition 4 assumes a relationship between invested resources and communication interactivity. The empirical findings reveal that both items, monetary as well as time resources correlate with the calculated interactivity. Additionally, a more detailed analysis of the communication indicators discloses a linear connection between the monetary resources and the perceived interactivity as well as the information frequency. By increasing the tolerable significance level to $p=0.068$, an interrelation between the time resources and information frequency can also be verified. Based on the described connections, especially the relationship between the resources and the calculated interactivity, proposition 4 of this study is supported. The findings seem to confirm the cited literature, which emphasizes the potential influence of the employed resources towards the stakeholder communication (e. g. Picazo-Vela et al. 2012). Furthermore, regarding proposition 5, the empirical data reveals a relationship between the calculated interactivity and the amount of fans. By analysing the individual communication indicators, interrelations between the amount of fans and the perceived interactivity as well as the information frequency can be confirmed. Therefore it is possible to support proposition 5. These results also seem to be in compliance with the social media literature that highlights information access, content and frequency as chief motivating factors to become a fan of a utility's Facebook account (Swani et al. 2013; Bauer et al. 2012; Bürger 2015). As the final proposition of this study, proposition 6 suggests an interrelationship between the invested resources and the communication outcome. In this regard, a connection between the monetary resources and the amount of fans is confirmed. Still, a connection between the time resources and the amount of fans cannot be verified. Consequently, proposition 6 is only partly supported. The support of all the described propositions is summarized in Table 3. 


\section{Research and Managerial Implications}

This study contributes to the current social media literature by analysing the interrelations between the company specification, communication interactivity, invested resources and communication outcomes. The results provide new insights for scholars and practitioners into the Facebook conversations of public entities in Austria, Germany and Switzerland. Due to the relatively low number of participating companies, the empirical data do not allow a country comparison. Still, such comparison could add a cultural component to the social media discussion and should therefore be emphasized in future studies. Regarding the key item "communication interactivity", follow-up studies need to more closely focus on the actual quality of the content, including the choice of topics and their presentation on the Facebook page. Besides, the influence of the control variable "year of account creation" towards the investigated resources, communication interactivity and the outcome should be investigated in more detail. When it comes to practitioners, the empirical data indicates that especially a utility's use of sufficient resources as well as interactive communication seem to be necessary prerequisites for Facebook users to become fans of a site.

Acknowledgements The author is thankful to Mag. Daniela Wetzelhütter, research fellow for empirical social research, University of Applied Sciences, Linz, Austria, for the valuable discussions regarding the analysis and interpretation of the empirical data. Moreover, the author is grateful to Linda Tuttle Weidinger, B. A., instructor of English, University of Applied Sciences and University of Education, Linz, Austria, for her language assistance and proofreading. The author has disclosed that he has no significant relationship with or financial interest in any commercial companies pertaining to this article.

Funding Open access funding provided by University of Applied Sciences Upper Austria.

Open Access This article is distributed under the terms of the Creative Commons Attribution 4.0 International License (http:// creativecommons.org/licenses/by/4.0/), which permits unrestricted use, distribution, and reproduction in any medium, provided you give appropriate credit to the original author(s) and the source, provide a link to the Creative Commons license, and indicate if changes were made.

\section{References}

Agostino D (2013) Using social media to engage citizens: a study of Italian municipalities. Public Relat Rev 39(3):232-234

Assmussen B, Harridge-March S, Occhiocupo N, Farquhar J (2013) The multi-layered nature of the internet-based democratization of brand management. J Bus Res 66(9):1473-1483

Baltar F, Brunet I (2012) Social research 2.0: virtual snowball sampling method using Facebook. Internet Res 22(1):57-74

Bauer H, Toma B, Fischer D (2012) Die Facebook-Fanpage - Effektive Gestaltung und kommunikationspolitische Wirkung. Mark Rev St Gallen 29(4):35-41
Bonsón E, Torres L, Royo S, Flores F (2012) Local e-government 2.0: Social media and corporate transparency in municipalities. Gov Inf Q 29(2):123-132

Bonsón E, Royo S, Ratkai M (2015) Citizens' engagement on local governments' Facebook sites. An empirical analysis: the impact of different media and content types in Western Europe. Gov Inf Q 32(1):52-62

Bortree DS, Seltzer T (2009) Dialogic strategies and outcomes: an analysis of environmental advocacy groups' Facebook profiles. Public Relat Rev 35(3):317-319

Bürger T (2015) Use of digital advocacy by German nonprofit foundations on Facebook. Public Relat Rev 41(4):523-525

Cho M, Schweickart T, Haase A (2014) Public engagement with nonprofit organizations on Facebook. Public Relat Rev 40(3):565-567

Chun SA, Reyes LFL (2012) Social media in government. Gov Inf Q 29(4):441-445

Criado JI, Sandoval-Almazan R, Gil-Garcia JR (2013) Government innovation through social media. Gov Inf Q 30(4):319-326

Cuppen E (2012) Diversity and constructive conflict in stakeholder dialogue: considerations for design and methods. Policy Sci 45(1):23-46

Dechange A, Friedrich B (2013) Multiprojektmanagement in der Energiewirtschaft. In: Lau C, Dechange A, Flegel T (eds) Projektmanagement im Energiebereich. Springer Gabler, Wiesbaden, pp 101-124

Dekay SH (2012) How large companies react to negative Facebook comments. Corp Commun Int J 17(3):289-299

Donaldson T, Preston LE (1995) The stakeholder theory of the corporation, concepts, evidence, and implications. Acad Manag Rev 20(1):65-91

Driessen PH, Kok RAW, Hillebrand B (2013) Mechanisms for stakeholder integration: bringing virtual stakeholder dialogue into organizations. J Bus Res 66(9):1465-1472

Facebook (2017a) News feed content. https://www.facebook.com/ help/316840001710276?helpref=search\&sr=1\&query=news. Accessed 19 Sept 2017

Facebook (2017b) Sequence of information. https://www.facebook. com/help/218728138156311?helpref=faq_content. Accessed 19 Sept 2017

Facebook (2017c) User settings. https://www.facebook.com/help/ 371675846332829?helpref=related\&ref=related. Accessed 19 Sept 2017

Freeman RE (1984) Strategic management: a stakeholder approach. Cambridge University Press, Boston

Freeman RE, Evan WM (1990) Corporate governance: a stakeholder interpretation. J Behav Econ 19(4):337-359

Garcia-Milian R, Norton HF, Tennant MR (2012) The presence of academic health sciences libraries on Facebook: the relationship between content and library popularity. Med Ref Serv Q 31(2):171-187

Haigh MM, Brubaker P, Whiteside E (2013) Facebook: examining the information presented and its impact on stakeholders. Corp Commun Int J 18(1):52-69

Hofmann S, Beverungen D, Räckers M, Becker J (2013) What makes local governments' online communication successful? Insights from a multi-method analysis of Facebook. Gov Inf Q 30(4):387-396

Kim S, Kim S-Y, Sung K-H (2014) Fortune 100 companies' Facebook strategies: corporate ability versus social responsibilities. J Commun Manag 18(4):343-362

Korschun D, Du S (2013) How virtual corporate social responsibility dialogues generate value: a framework and propositions. J Bus Res 66(9):1494-1504

Leung XY, Tanford S (2016) What drives Facebook fans to 'like' hotel pages: a comparison of three competing models. J Hosp Mark Manag 25(3):314-345 
Lovari A, Parisi L (2015) Listening to digital publics. Investigating citizens' voices and engagement within Italian municipalities' Facebook pages. Public Relat Rev 41(2):205-213

Manetti G, Bellucci M, Bagnoli L (2016) Stakeholder engagement and public information through social media: a study of Canadian and American public transportation agencies. Am Rev Public Adm 47(8):991. https://doi.org/10.1177/0275074016649260

Martin S (2016) The rise of Facebook-based communication in the energy sector. Zeitschrift Für Energiewirtschaft 40(2):89-96

Martin S, Grueb B (2016) Towards a process of agenda setting driven by social media. Int J Energy Sect Manag 10(1):38-55

Mergel I (2012) The social media innovation challenge in the public sector. Inf Polity 17(3-4):281-292

Mergel I (2013) A framework for interpreting social media interactions in the public sector. Gov Inf Q 30(4):327-334

Mergel I, Bretschneider SI (2013) A three-stage adoption process for social media use in government. Public Adm Rev 73(3):390-400

Merilainen N, Vos M (2011) Human rights organizations and online agenda setting. Corp Commun Int J 16(4):293-310

Mossberger K, Yonghong W, Crawford J (2013) Connecting citizens and local governments? Social media and interactivity in major U.S. cities. Gov Inf Q 30(4):351-358

Mühlbacher H, Kornum N (2013) Multi-stakeholder virtual dialogue: introduction to the special issue. J Bus Res 66(9):1460-1464

Nah S, Saxton GD (2012) Modeling the adoption and use of social media by nonprofit organizations? N Media Soc 15(2):294-313

Oliveira GHM, Welch EW (2013) Social media use in local government: linkage of technology, task, and organizational context. Gov Inf Q 30(4):397-405

O'Riordan L, Fairbrass J (2008) Corporate social responsibility, (CSR) models and theories in stakeholder dialogue. J Bus Ethics 83(4):745-758

Pedersen ER (2006) Making corporate social responsibility (CSR) operable: how companies translate stakeholder dialogue into practice. Bus Soc Rev 111(2):137-163

Pedersen AGJ, Lagergaard D, Sanderhoff M (2013) Der Stakeholderdialog in Geschäftsberichten: Eine Analyse der dargestellten Dialogbereitschaft europäischer Energieunternehmen. Umweltwirtschaftsforum 21(1/2):97-104
Phillips R, Freeman RE, Wicks AC (2003) What stakeholder theory is not. Bus Ethics Q 13(4):479-502

Picazo-Vela S, Gutiérrez-Martínez I, Luna-Reyes LF (2012) Understanding risks, benefits, and strategic alternatives of social media applications in the public sector. Gov Inf Q 29(4):504-511

Rasche A, Daniel EE (2006) From stakeholder management to stakeholder accountability. J Bus Ethics 65(3):251-267

Sharif MHM, Troshani I, Davidson R (2015) Public sector adoption of social media. J Comput Inf Syst 55(4):53-61

Statista (2015) Anzahl aktiver Nutzer von Facebook in der Schweiz von März 2013 bis Dezember 2015 (in Millionen). http://de. statista.com/statistik/daten/studie/70221/umfrage/anzahl-dernutzer-von-facebook-in-der-schweiz/. Accessed 15 July 2016

Statista (2016a) Anzahl der Nutzer von Facebook und Instagram in Deutschland im Jahr 2016 (in Millionen). http://de.statista.com/ statistik/daten/studie/503046/umfrage/anzahl-der-nutzer-vonfacebook-und-instagram-in-deutschland/. Accessed 15 July 2016

Statista (2016b) Anzahl der Nutzer von Facebook in Österreich in ausgewählten Monaten von April 2013 bis Januar 2016 (in Millionen). http://de.statista.com/statistik/daten/studie/296115/ umfrage/facebook-nutzer-in-oesterreich/. Accessed 15 July 2016

Swani K, Milne G, Brown BP (2013) Spreading the word through likes on Facebook. J Res Interact Mark 7(4):269-294

Wallsten K (2007) Agenda setting and the blogosphere: an analysis of the relationship between mainstream media and political blogs. Rev Policy Res 24(6):567-587

Waters RD, Burnett E, Lamm A, Lucas J (2009) Engaging stakeholders through social networking: how nonprofit organizations are using Facebook. Public Relat Rev 35(2):102-106

Witt P (2013) Innovationsmanagement in Energieversorgungsunternehmen. In: Lau C, Dechange A, Flegel T (eds) Projektmanagement im Energiebereich. Springer Gabler, Wiesbaden, pp 53-68

Yang A, Kent M (2014) Social media and organizational visibility: a sample of fortune 500 corporations. Public Relat Rev 40(3):562-564

Yi M, Oh SG, Kim S (2013) Comparison of social media use for the U.S. and the Korean governments. Gov Inf Q 30(3):310-317 